\title{
A cardiac and subcutaneous canine dirofilariosis outbreak in a kennel in central France
}

\author{
Younes Laidoudi ${ }^{1,2}$, David Ringot ${ }^{3}$, Stéphanie Watier-Grillot ${ }^{4,5}$, Bernard Davoust ${ }^{1,2,4, *}$, and Oleg Mediannikov ${ }^{1,2}$ \\ 1 Aix Marseille Univ, IRD, APHM, MEPHI, IHU Méditerranée Infection, 13385, Marseille, France \\ ${ }^{2}$ IHU Méditerranée Infection, 13385 Marseille, France \\ ${ }^{3}$ French Military Health Service, $33^{\text {e }}$ Veterinary Group, 37076 Tours, France \\ 4 Animal Epidemiology Working Group of the Military Health Service, 13014 Marseille, France \\ ${ }^{5}$ French Armed Forces Centre for Epidemiology and Public Health (CESPA), 13014 Marseille, France
}

Received 29 November 2019, Accepted 5 December 2019, Published online 16 December 2019

\begin{abstract}
Canine dirofilarioses are nematode infections caused by two species of the genus Dirofilaria: D. immitis and $D$. repens. We describe here an outbreak of $D$. immitis and D. repens infection in military working dogs (MWDs) housed in a kennel in the Indre department (centre of France). Out of a total of 17 dogs, 6 (35.2\%) tested positive for $D$. immitis, D. repens or both parasites. Infested dogs were treated and prophylactic measures were implemented for the entire kennel staff. To our knowledge, this is the first documented description of an outbreak of canine cardiopulmonary dirofilariasis in the center of France, unlike in the south of this country, where D. immitis and D. repens dirofilariasis are enzootic. In France, as mosquito vectors expand their territory and new non-native vectors are introduced, it is likely that the distribution area of these two diseases of domestic and wild carnivores will be wider and underestimated.
\end{abstract}

Key words: Dirofilaria immitis, Dirofilaria repens, Heartworm disease, PCR, Military working dog, France.

\begin{abstract}
Résumé - Un foyer de dirofilariose canine cardiaque et sous-cutanée dans un chenil du centre de la France. Les dirofilarioses canines sont des infections à nématodes causée par deux espèces du genre Dirofilaria, D. immitis et $D$. repens. Nous décrivons ici un foyer d'infection à $D$. immitis et $D$. repens chez des chiens militaires hébergés dans un chenil dans le département de l'Indre (centre de la France). Sur un total de 17 chiens, 6 (35, $2 \%$ ) ont été testés positifs pour $D$. immitis, pour $D$. repens ou pour les deux parasites. Les chiens infestés ont été traités et des mesures prophylactiques ont été mises en place pour tout le personnel du chenil. À notre connaissance, il s'agit de la première description documentée d'un foyer de dirofilariose cardiopulmonaire canine dans le centre de la France, contrairement au sud du pays, où les dirofilarioses à $D$. immitis et $D$. repens sont enzootiques. En France, à mesure que les moustiques vecteurs élargissent leur territoire et que de nouveaux vecteurs non indigènes sont introduits, il est probable que la zone de distribution de ces deux maladies des carnivores domestiques et sauvages sera plus étendue et sous-estimée.
\end{abstract}

\section{Introduction}

Dirofilaria immitis (Leidy, 1856) [23] and Dirofilaria repens Railliet \& Henry, 1911 [33] are mosquito-borne filarioids (Nematoda: Onchocercidae) infecting wild and domestic mammals of different orders with canids as the predominant definitive hosts. Adult worms of $D$. immitis with a smooth cuticle (measuring between $12 \mathrm{~cm}$ and $30 \mathrm{~cm}$ in length) colonize the pulmonary arteries and right heart cavities, whereas adult worms of $D$. repens, with a finely striated cuticle, (measuring between $5 \mathrm{~cm}$ and $17 \mathrm{~cm}$ in length) are located in the subcutaneous tissues [11,26, 28]. About 120 days after infection of the

*Corresponding author: bernard. davoust@gmail.com mammalian host, the viviparous female can be fertilized and produces mobile embryos called microfilariae. Microfilariae (L1 stage) parasitize the blood until being ingested by the mosquito vector (Culicidae) during a blood meal taken on a microfilaremic host. Inside the vector, microfilariae first develop into larval stage 1 (L1), then molt into larval stage 2 (L2), and finally molt into third-stage larvae (L3), which is the infective stage. Clinically, D. immitis infection (canine heartworm disease) can remain unapparent for a long time. Symptoms are mainly dominated by right heart failure, ranging from exercise intolerance and fatigue to cardiac decompensation with swelling and possible acute pulmonary oedema $[12,26,29]$. In contrast, the infestation by $D$. repens often passes unnoticed. Dogs infected with $D$. repens microfilariae 
may sometimes develop subcutaneous nodules where adult worms encyst. Sometimes, the disease manifests with more symptoms, such as pruritus and skin changes [38].

Canine dirofilariosis has been known in France for a long time. It was in 1679 that Panhot highlighted heartworm in a dog native to the Dombes region (near Lyon) [30]. Over the last century, several studies have shown the importance of this parasitosis in the Mediterranean region [8, 18]. At the beginning of the 1980s, the infestation rate of military working dogs (MWDs) was high, particularly in Corsica and the Bouchesdu-Rhône department [5, 8]. Out of 180 MWDs tested in 1988, $67(37 \%)$ carried microfilariae in the blood, including 17 cases of $D$. immitis, 2 of $D$. repens, 15 mixed infestations and 3 doubtful ones [5]. A screening test carried out on 85 MWDs from northern France (Brittany and Normandy) was negative [6]. The MWDs with heartworm disease may lose their operational fitness, causing an operational impact for the Armed Forces. In fact, MWDs military dogs are used for the detection of explosive devices as well as to secure military sites. The eradication of canine heartworm disease among military dogs in south-eastern France was made possible by the implementation, for the first time in France, of chemoprophylaxis based on the use of ivermectin, completed by a conclusive trial on the efficacy of melarsomine in treating adult Dirofilaria [4]. The first demonstration of the long-term effectiveness of this protocol was made in 2015 by comparing the incidence rates of $D$. immitis infestation in MWDs from a kennel located in Corsica and in co-located civilian dogs (the civilian kennel was less than $15 \mathrm{~km}$ from the military kennel). The estimated prevalence in civilian dogs was $40.4 \%$ (19/47), while no cases were identified in MWDs [36]. Currently, canine dirofilarioses chemoprophylaxis is applied to all MWDs deployed on missions outside mainland France, as well as to MWDs from mainland France located in south-eastern France, during the period of vector activity (May-November). In the present study, we revealed the existence of an indigenous outbreak of $D$. immitis and $D$. repens infestation in the French department of Indre. To the best of our knowledge, this is the first documented description of an outbreak of canine cardiopulmonary dirofilariosis in this region of France.

\section{Materials and methods \\ Dogs}

In October 2018, we performed blood tests on the 17 apparently healthy dogs in the military kennel located near the city of Rosnay $\left(46^{\circ} 42^{\prime} 47^{\prime \prime} \mathrm{N}, 1^{\circ} 14^{\prime} 39^{\prime \prime} \mathrm{E}\right)$, in Indre, central France. The commune is located in the "Parc naturel régional de la Brenne". The MWDs, including 11 Belgian Malinois and 6 German Shepherds, were all males aged 2-10 years, with a median of 5 years. The duration of the dogs' presence in the kennel ranged from 6 months to 8.5 years, with a median of 4 years. MWDs, including dogs from the Rosnay kennel, are purchased abroad, mainly in eastern European countries (Germany and Poland, in particular). They arrived at the kennel at about 2 years of age. They received regular veterinary care. From May to October, they benefit from a treatment against ectoparasites, but which has no repellent effect on mosquitoes. For the purpose of the study, two blood samples of $4-5 \mathrm{~mL}$ volume were taken from each dog and collected from a dry tube and a citrated tube, respectively. Serum was collected after centrifugation (10 min, $3000 \mathrm{~g})$. Each animal sampled was examined clinically.

\section{Ethics statement}

Blood samples were collected in accordance with the requirements of the Animal Ethics Procedures of French veterinarians and with the consent of the owner of the animals (French Armed Forces).

\section{Direct detection of microfilariae}

Modified Knott's staining was chosen to identify canine blood microfilaria [21, 25]. One millilitre of citrated blood was mixed with $9 \mathrm{~mL}$ of hemolyzing solution (2\% acetic acid) in a $15 \mathrm{~mL}$ tube, followed by centrifugation for minutes at $500 \mathrm{rpm}$. The supernatant was removed; the sediment was stained with methylene-blue, transferred to a slide, and covered with a cover slip.

\section{Heartworm antigen detection}

Heartworm antigen detection was performed using two rapid diagnostic serological tests marketed in France and targeting the antigen secreted by the adult female worm: (i) a WITNESS $^{\circledR}$ Dirofilaria test (Zoetis, Lyon, France), based on immunomigration $\left(\mathrm{RIM}^{\circledR}\right)$ technology, and (ii) a DiroCHEK ${ }^{\circledR}$ test (Zoetis, Lyon, France), based on an enzyme-linked immunosorbent assay method known as a sandwich ELISA. Both tests provide rapid results, as well as high sensitivity (99\% for WITNESS ${ }^{\circledR}$ Dirofilaria and $98 \%$ for DiroCHEK ${ }^{\circledR}$ ) and specificity $\left(94 \%\right.$ for WITNESS ${ }^{\circledR}$ Dirofilaria and $96 \%$ for DiroCHEK $\left.^{\circledR}\right)$ [17].

\section{Molecular detection of filaria and the Wolbachia endosymbiont of filaria}

DNA was extracted from $100 \mu \mathrm{L}$ of citrated blood, after 4-hour digestion at $56{ }^{\circ} \mathrm{C}$, using an equal volume of buffer $\mathrm{G} 2$ supplemented with $15 \%$ proteinase $\mathrm{K}$. The extraction was performed using the Biorobot EZ1 System with the EZ1 DNA tissue kit (Qiagen, Courtaboeuf, France), in line with the manufacturer's instructions. DNA was eluted in a final volume of $100 \mu \mathrm{L}$ and stored at $-20{ }^{\circ} \mathrm{C}$. All samples were screened for filaria and their Wolbachia complex, using the fast typing approach which consists in a pan-filarial 28S-based qPCR system, followed by a triplex COI-based system targeting D. immitis, D. repens and Acanthocheilonema reconditum, and the duplex ftsZ-based system, targeting specifically the Wolbachia endosymbiont of $D$. immitis and that of $D$. repens (Table 1) [22]. Once the specific filarial DNA has been revealed by the qPCR triplex, the sample is considered positive, and the detection of Wolbachia DNA confirms infection by D. immitis or $D$. repens related to this strain. 
Table 1. Primers and probes used in this study.

\begin{tabular}{|c|c|c|c|c|}
\hline System name & Primer \& probe name & Sequences $5^{\prime}-3^{\prime}$ & Specificity & References \\
\hline \multirow{3}{*}{$\begin{array}{l}\text { Pan-fil 28S qPCR- } \\
\text { based system }\end{array}$} & qFil-28S-F & TTGTTTGAGATTGCAGCCCA & \multirow[t]{3}{*}{ Filariae } & \multirow[t]{19}{*}[22]{} \\
\hline & qFil-28S-P & $\begin{array}{l}\text { 6FAM-5'-CAAGTACCGTGAGGGAAAGT-3'- } \\
\text { TAMRA }\end{array}$ & & \\
\hline & qFil-28S-R & GTTTCCATCTCAGCGGTTTC & & \\
\hline \multirow{3}{*}{$\begin{array}{l}\text { All-Wol 16S qPCR- } \\
\text { based system }\end{array}$} & all.Wol.16S.301-F & TGGAACTGAGATACGGTCCAG & \multirow[t]{3}{*}{ Wolbachieae } & \\
\hline & all.Wol.16S.347-P & $\begin{array}{l}\text { 6FAM-5'-AATATTGGACAATGGGCGAA-3' } \\
\text { TAMRA }\end{array}$ & & \\
\hline & all.Wol.16S.478-R & GCACGGAGTTAGCCAGGACT & & \\
\hline \multirow{5}{*}{$\begin{array}{l}\text { Triplex TaqMan COI } \\
\text { qPCR-based system }\end{array}$} & Fil.COI.749-F & CATCCTGAGGTTTATGTTATTATTTT & & \\
\hline & D.imm.COI.777-P & $\begin{array}{l}\text { 6FAM-CGGTGTTTGGGATTGTTAGTG- } \\
\text { TAMRA }\end{array}$ & Dirofilaria immitis & \\
\hline & D.rep.COI.871-P & $\begin{array}{l}\text { 6VIC-TGCTGTTTTAGGTACTTCTGTTTGAG- } \\
\text { TAMRA }\end{array}$ & Dirofilaria repens & \\
\hline & A.rec.COI.866-P & Cy5-TGAATTGCTGTACTGGGAACT-BHQ-3 & \multirow[t]{2}{*}{$\begin{array}{l}\text { Acanthocheilonema } \\
\text { reconditum }\end{array}$} & \\
\hline & Fil.COI.914-R & CWGTATACATATGATGRCCYCA & & \\
\hline \multirow{4}{*}{$\begin{array}{l}\text { Duplex Wol-Diro ftsZ } \\
\text { qPCR-based system }\end{array}$} & WDiro.ftsZ.490-F & AAGCCATTTRGCTTYGAAGGTG & \multirow{4}{*}{$\begin{array}{l}\text { Wolbachia endosymbiont } \\
\text { of } D \text {. immitis and } \\
\text { D. repens }\end{array}$} & \\
\hline & WDimm.ftsZ.523-P & $\begin{array}{l}\text { 6FAM-CGTATTGCAGAGCTCGGATTA- } \\
\text { TAMRA }\end{array}$ & & \\
\hline & WDrep.ftsZ.525-P & $\begin{array}{l}\text { 6VIC-CATTGCAGAACTGGGACTGG- } \\
\text { TAMRA }\end{array}$ & & \\
\hline & WDiro.ftsZ.600-R & AAACAAGTTTTGRTTTGGAATAACAAT & & \\
\hline \multirow{4}{*}{$\begin{array}{l}\text { Duplex HWs COI } \\
\text { qPCR-based system }\end{array}$} & Hw.COI.723-F & TCAGCATTTGTTTTGGTTTTT & & \\
\hline & D.imm.COI.777-P & $\begin{array}{l}\text { 6FAM-CGGTGTTTGGGATTGTTAGTG- } \\
\text { TAMRA }\end{array}$ & D. immitis & \\
\hline & A.vas.COI.813-P & $\begin{array}{l}\text { 6VIC-TGACTGGGAAGAAGGAGGTG- } \\
\text { TAMRA }\end{array}$ & \multirow[t]{2}{*}{ Angiostrongylus vasorum } & \\
\hline & Hw.COI.950-R & GCASTAAAATAAGYACGAGWATC & & \\
\hline \multirow{2}{*}{$\begin{array}{l}\text { Pan-Nematoda primers } \\
\text { 18S PCR-based } \\
\text { system }\end{array}$} & Fwd.18S.631 & TCGTCATTGCTGCGGTTAAA & \multirow[t]{2}{*}{ Nematoda } & \multirow[t]{2}{*}{ This study } \\
\hline & Rwd.18S.1825r & GGTTCAAGCCACTGCGATTAA & & \\
\hline
\end{tabular}

\section{Sequencing analysis and phylogenetic genotyping of filaria}

Samples harbouring a single DNA of filaria were subjected to sequencing analysis. The pan-Nematoda primers named Fwd.18S.631 \& Rwd.18S.1825r (Table 1) were designed and customized to amplify an 1127-1155-bp fragment from the $18 \mathrm{~S}$ rRNA gene. PCR reactions were carried out in a total volume of $50 \mu \mathrm{L}$, consisting of $25 \mu \mathrm{L}$ of AmpliTaq Gold master mix, $18 \mu \mathrm{L}$ of ultra-purified water DNAse-RNAse free, $1 \mu \mathrm{L}$ of each primer and $5 \mu \mathrm{L}$ of DNA template. The thermal cycling conditions were: incubation step at $95{ }^{\circ} \mathrm{C}$ for $15 \mathrm{~min}$, 40 cycles of $1 \mathrm{~min}$ at $95{ }^{\circ} \mathrm{C}, 30 \mathrm{~s}$ at $54{ }^{\circ} \mathrm{C}$ for the melting temperature, and one and half minutes for the elongation time at $72{ }^{\circ} \mathrm{C}$, followed by a final extension of $5 \mathrm{~min}$ at $72{ }^{\circ} \mathrm{C}$. PCR amplification was performed in a Peltier PTC-200 model thermal cycler (MJ Research Inc., Watertown, MA, USA). The DNA generated through the PCR reaction was purified by filtration using a NucleoFast ${ }^{\circledR} 96$ PCR DNA purification plate, and was then amplified using a BigDye ${ }^{\circledR}$ Terminator v3.1 Cycle Sequencing Kit (Applied Biosystems, Foster City, CA, USA). The BigDye PCR products were purified on the Sephadex G-50 Superfine gel filtration resin prior to sequencing on the ABI Prism 3130XL. Nucleotide sequences were assembled and corrected using ChromasPro 2.0.0, then aligned against close reference sequences of filarioids species, representative members of Onchocercidae available in GenBank. The alignment was performed using the ClustalW application within BioEdit v.7.2.5 [16]. The maximum likelihood phylogenetic tree was inferred on MEGA6 [37], based on the Kimura 3-substitution-type model [20].

\section{Results and discussion}

Table 2 presents the results of the nine analyses carried out on the blood of 17 MWDs of the Rosnay kennel. For canine dirofilariosis, we observed $35.2 \%(6 / 17)$ positive dogs. The Knott test conducted on dog No. 3 revealed the presence of D. immitis microfilariae. DNA and Wolbachia complex qPCRs tests as well as the two serological tests gave positive results. Five dogs had mixed infestation with $D$. immitis and D. repens (dogs Nos. 2, 7, 8, 10 and 13). Dirofilaria repens DNA was identified in dogs Nos. 2, 10 and 13. Furthermore, both Wolbachia genotypes known to be associated with $D$. immitis and $D$. repens were also detected in the same samples. Two samples (Nos. 2 and 13) provided positive results with both serological tests. One dog (No. 7) was positive for both $D$. immitis and D. repens microfilariae by the Knott test, the PCR test for both Dirofilaria and Wolbachia DNA, and by 
Table 2. Screening for dirofilariosis in a military kennel in the Indre department (central France)

\begin{tabular}{|c|c|c|c|c|c|c|c|c|c|c|c|c|c|c|}
\hline \multirow[t]{2}{*}{$\begin{array}{l}\text { Dog } \\
\text { number } \\
\text { (No.) }\end{array}$} & \multirow[t]{2}{*}{ Breed* } & \multirow[t]{2}{*}{$\begin{array}{l}\text { Age } \\
\text { (year) }\end{array}$} & \multirow[t]{2}{*}{$\begin{array}{c}\text { Kennel } \\
\text { presence } \\
\text { time } \\
\text { (year) }\end{array}$} & \multirow[t]{2}{*}{$\begin{array}{l}\text { Parasitological } \\
\text { diagnosis: } \\
\text { Knott test }\end{array}$} & \multicolumn{2}{|c|}{$\begin{array}{l}\text { Serological } \\
\text { screening }\end{array}$} & \multirow{2}{*}{$\begin{array}{l}\text { Molecular } \\
\text { detection of } \\
\text { filarial DNA using } \\
\text { the qPCR } \\
\text { Pan-Filaria 28S }\end{array}$} & \multirow[t]{2}{*}{$\begin{array}{l}\text { Genotyping: } \\
\text { 18S rRNA } \\
\text { gene }\end{array}$} & \multirow{2}{*}{\multicolumn{3}{|c|}{$\begin{array}{c}\text { Molecular identification } \\
\text { of filarial species using a COI } \\
\text { Triplex qPCR-based system } \\
\text { Dirofilaria Dirofilaria Acanthocheilonema } \\
\text { immitis repens reconditum }\end{array}$}} & \multicolumn{2}{|c|}{$\begin{array}{l}\text { Molecular identification of } \\
\text { Wolbachia genotypes using } \\
\text { ftsZ duplex qPCR-based } \\
\text { system }\end{array}$} & \multirow[t]{2}{*}{ Diagnosis } \\
\hline & & & & & $\begin{array}{l}\text { Witnesss }{ }^{\circledR} \\
\text { Dirofilaria }\end{array}$ & DiroCHEK ${ }^{\circledR}$ & & & & & & $\begin{array}{c}\text { Wolbachia } \\
\text { endosymbiont } \\
\text { of D. immitis } \\
\end{array}$ & $\begin{array}{c}\text { Wolbachia } \\
\text { endosymbiont } \\
\text { of D. repens }\end{array}$ & \\
\hline 1 & BSM & 10 & 8.5 & Neg. & Neg. & Neg. & Neg. & $\mathrm{NE}^{* *}$ & Neg. & Neg. & Neg. & Neg. & Neg. & Healthy dog \\
\hline 2 & BSM & 7 & 6 & D. repens & Pos. & Pos. & Pos. & D. repens & Neg. & Pos. & Neg. & Pos. & Pos. & $\begin{array}{l}\text { Occult heartworm and } \\
\text { subcutaneous dirofilariosis }\end{array}$ \\
\hline 3 & GS & 6 & 5 & D. immitis & Pos. & Pos. & Pos. & D. immitis & Pos. & Neg. & Neg. & Pos. & Neg. & Heartworm disease \\
\hline 4 & BSM & 6 & 5 & Neg. & Neg. & Neg. & Neg. & $\mathrm{NE}$ & Neg. & Neg. & Neg. & Neg. & Neg. & Healthy dog \\
\hline 5 & BSM & 6 & 5 & Neg. & Neg. & Neg. & Neg. & $\mathrm{NE}$ & Neg. & Neg. & Neg. & Neg. & Neg. & Healthy dog \\
\hline 6 & BSM & 6.5 & 5 & Neg. & Neg. & Neg. & Neg. & $\mathrm{NE}$ & Neg. & Neg. & Neg. & Neg. & Neg. & Healthy dog \\
\hline 7 & GS & 6 & 4 & $\begin{array}{l}\text { D. } \underset{\text { immitis }+D .}{\text { repens }}\end{array}$ & Neg. & Pos. & Pos. & $\mathrm{NE}$ & Pos. & Pos. & Neg. & Pos. & Pos. & $\begin{array}{c}\text { Heartworm and subcutaneous } \\
\text { dirofilariosis }\end{array}$ \\
\hline 8 & BSM & 4.5 & 3 & Neg. & Neg. & Neg. & Pos. & $\mathrm{NE}$ & Pos. & Pos. & Neg. & Pos. & Pos. & $\begin{array}{l}\text { Occult heartworm and } \\
\text { subcutaneous dirofilariosis }\end{array}$ \\
\hline 9 & GS & 3.5 & 2.5 & Neg. & Neg. & Neg. & Neg. & $\mathrm{NE}$ & Neg. & Neg. & Neg. & Neg. & Neg. & Healthy dog \\
\hline 10 & BSM & 4 & 2 & D. repens & Neg. & Neg. & Pos. & D. repens & Neg. & Pos. & Neg. & Pos. & Pos. & $\begin{array}{l}\text { Occult heartworm and } \\
\text { subcutaneous dirofilariosis }\end{array}$ \\
\hline 11 & BSM & 3 & 2 & Neg. & Neg. & Neg. & Neg. & $\mathrm{NE}$ & Neg. & Neg. & Neg. & Neg. & Neg. & Healthy dog \\
\hline 12 & GS & 3 & 2 & Neg. & Neg. & Neg. & Neg. & $\mathrm{NE}$ & Neg. & Neg. & Neg. & Neg. & Neg. & Healthy dog \\
\hline 13 & GS & 4 & 1.5 & D. repens & Pos. & Pos. & Pos. & D. repens & Neg. & Pos. & Neg. & Pos. & Pos. & $\begin{array}{l}\text { Occult heartworm and } \\
\text { subcutaneous dirofilariosis }\end{array}$ \\
\hline 14 & GS & 2.5 & 1.5 & Neg. & Neg. & Neg. & Neg. & $\mathrm{NE}$ & Neg. & Neg. & Neg. & Neg. & Neg. & Healthy dog \\
\hline 15 & BSM & 3.5 & 1 & Neg. & Neg. & Neg. & Neg. & $\mathrm{NE}$ & Neg. & Neg. & Neg. & Neg. & Neg. & Healthy dog \\
\hline 16 & BSM & 2 & 0.5 & Neg. & Neg. & Neg. & Neg. & NE & Neg. & Neg. & Neg. & Neg. & Neg. & Healthy dog \\
\hline 17 & BSM & 2 & 0.5 & Neg. & Neg. & Neg. & Neg. & $\mathrm{NE}$ & Neg. & Neg. & Neg. & Neg. & Neg. & Healthy dog \\
\hline
\end{tabular}

"BSM: Belgian shepherd malinois, GS: German shepherd.

NE: Not evaluated. 


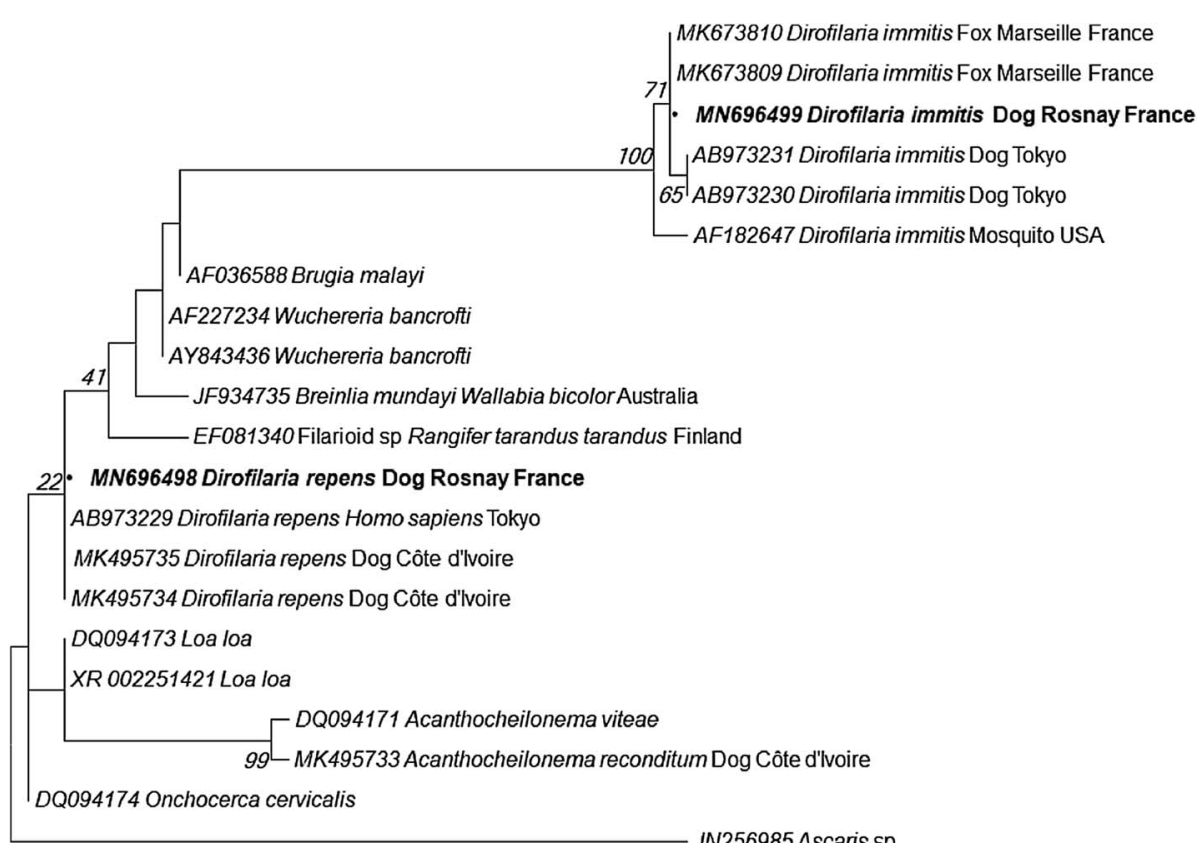

IN256985 Ascaris sp.

$\stackrel{\longmapsto}{0.005}$

Figure 1. Molecular phylogenetic analysis of the 18S rRNA gene, using the maximum likelihood method based on the Kimura 3-substitutiontype model.

ELISA; whereas, it was negative by the immunomigration test. Finally, dog No. 8 was positive for $D$. immitis and D. repens and Wolbachia DNA; and for both serological tests. All samples were free of $A$. reconditum infection.

Four partial sequences of the 18S rRNA gene have been successfully generated from samples identified as positive for a single DNA of filaria. Phylogenetic analysis revealed that dog No. 3 was infected with D. immitis, having $100 \%$ identity with D. immitis isolated from foxes in France (Marseille) (MK673809, MK673810) and 99.9\% with that isolated from dogs in Japan (AB973231). Three D. repens sequences were $100 \%$ identical both to each other and to D. repens isolated from humans in Japan (Fig. 1).

Dog No. 7 died suddenly in November 2018 (1 month after blood sampling for our study) because of a stomach dilationtorsion. The necropsy performed on this dog revealed the presence in the right heart of four females and two males of D. immitis (Fig. 2). The heart was not dilated.

It is known that heartworm can occur as an occult infestation, resulting in the presence of at least one mature female (or male) of D. immitis, without circulating microfilariae. Occult infestations occur in several situations, including monosexual infestation by male or female worms only, infertility of female worms, low infestation levels and/or destruction of microfilariae due to the host's immune response [35]. In our study, the proportion of occult infestation among dogs infected by $D$. immitis was $66.6 \%$ (4/6). The detection of occult infections is usually based on adult worm antigen testing [24]. However, in areas endemic for both $D$. immitis and $D$. repens, the reliability of these tests decreases, due to two main factors: (i) cross-reaction of rapid diagnostic tests between $D$. immitis and other parasites, including D. repens, and (ii) the immunosuppressive capacity

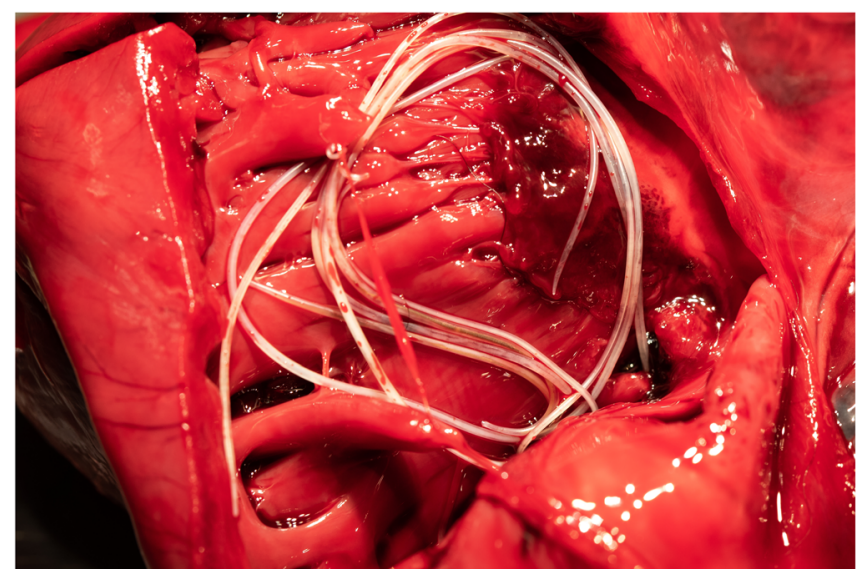

Figure 2. Heartworm (Dirofilaria immitis) in the right ventricle of dog No. 7.

of $D$. repens over D. immitis microfilariae, which hinders diagnosis based on the detection of blood microfilariae [14]. Adulticide treatment of $D$. immitis dirofilariasis, according to the protocol recommended by the American Heartworm Society, was effective against $D$. repens [28]. The approach combining the specific detection of molecular markers of D. immitis and D. repens showed $100 \%$ and $99.3 \%$ sensitivity and specificity, respectively. The reliability of the method is not reduced, even in case of occult dirofilariasis possibly accompanied by infestation by other filaroid species like Acanthocheilonema reconditum, leading to false positives following cross-reactions of rapid detection tests for D. immitis antigens [24]. This is coherent with the results obtained in our study, where occult heartworm 
infection associated with circulating microfilariae of $D$. repens was observed in 60\% (3/5) of Dirofilaria spp. coinfected dogs, of which only $40 \%(2 / 5)$ were positive for $D$. immitis antigen.

Canine filarial infections have increased significantly in recent years [35]. This trend is the consequence of the increase in the range of vectors, as well as the introduction of infected dogs, reservoirs of parasites, into ecosystems favourable to the emergence of secondary indigenous outbreaks. The geographical distribution of heartworm disease and subcutaneous dirofilariosis in France is not precisely known. However, several studies reported that $D$. repens is more endemic and spreads more rapidly than $D$. immitis within northern and eastern Europe [2, 3, 14, 31, 36]. These differences in the epidemiology of the two parasite species could be explained by the fact that in areas where $D$. repens is widespread, the progression of D. immitis would be hindered, and vice versa [14]. Outbreaks of $D$. immitis have also been reported in western France, they concerned hunting dogs living in kennels near ponds [6, 7]. In our study, the military kennel is located in an infertile swampy area near seven ponds. The local ecosystem is highly favourable to the development of dirofilariosis vectors. Aedes (Stegomyia) albopictus, more commonly known as the "tiger mosquito", has been introduced into metropolitan France from Italy and is now present throughout the south of the country, as well as in regions further north, including the Paris region and the department of Indre since 2017 [27]. This highly invasive and anthropophilic mosquito is known to be a competent vector of dirofilariosis parasites and to be implicated in the transmission of dirofilariosis in the studied area and most likely contributed to the infection of the military dogs considered in this study [36]. In southern Italy, the worrying increase in the proportion of mosquitoes infected by $D$. immitis among A. albopictus populations is associated with an increased risk of infestation of dogs with this parasite [15]. An integrated approach to control dirofilariosis vectors and to reduce infection sources and reservoirs for the parasite should be implemented in these areas. In the highly endemic area, the multi-modal prophylactic strategy, consisting in the administration of macrocyclic lactones and the application of repellents effective against mosquitoes, appears to be a tailored strategy.

A wide range of mammalian hosts, including humans and cats, can be infected by both $D$. immitis and $D$. repens, resulting from their low host specificity. Human infestation by $D$. immitis results in a pulmonary form (nodules), the most severe but less frequent form, which is found mainly in southern Europe (Italy, Spain, Greece, etc.) [13]. In France, most cases of human dirofilariasis caused by $D$. immitis are reported in endemic regions, such as Corsica and the Bouches-du-Rhône department $[9,32]$. In humans, like in dogs, D. repens causes subcutaneous filariasis [1, 19].

We report here for the first time, an outbreak of canine dirofilariosis (D. repens and D. immitis) in the Rosnay military kennel, with a health risk for military personnel and military dogs in this area. In late 2018, after the detection of several infected dogs in the kennel, the following management measures were implemented: all dogs infected by $D$. immitis and cases of mixed infection $(N=6)$, except one that died before the treatment was administered (dog No. 7), received adulticide (melarsomine), combined with larvicide treatment (ivermectin), doxycycline and glucocorticosteroids (prednisone), according to the treatment protocol recommended by the American Heartworm Society [28]. During treatment, a restriction on physical activity was prescribed. This treatment eliminated $D$. repens and D. immitis larvae, as well as Wolbachia complex and the existing susceptible larvae. Moreover, all infected dogs were treated with insecticidal repellent effective against mosquitoes during the period of vector activity (from May to November in mainland France). The aim was to prevent secondary cases and outbreaks, in the presence of competent vectors in the area where the military kennel is located.

\section{Conclusions}

The epidemiology of dirofilariosis infections is complex and has even been related to the concept of the episystem, represented by the multiple interactions between climate, environment, animals, humans and parasites [34]. As these are zoonoses, physicians and veterinarians must be informed of the risks of transmission in the regions, and especially the local biotopes [10]. We suggest that epidemiological investigations of vectors and canine dirofilariasis be implemented in areas at risk of exposure. Moreover, we suggest implementation of prevention against $D$. immitis and $D$. repens infection in dogs, using macrocyclic lactones [35], in combination with a repellent effective against mosquitoes (permethrin or deltamethrin-based products), as recommended for heartworm prevention in the affected and surrounding areas [28].

\section{Competing interests}

The authors declare that they have no competing interests.

Acknowledgements. The authors thank Florian Boisson for his help in dog health surveillance. This study was supported by the French Armed Forces Health Service and the Institut HospitaloUniversitaire (IHU) Méditerranée Infection, the National Research Agency under the program "Investissements d'avenir", reference ANR-10-IAHU-03, the Région Provence-Alpes-Côte d'Azur and European FEDER PRIMI funding. We thank Christophe Calleja (Zoetis) for supply of serological kits.

\section{References}

1. Benzaquen M, Brajon D, Delord M, Yin N, Bittar F, Toga I, Berbis P, Parola P. 2015. Cutaneous and pulmonary dirofilariasis due to Dirofilaria repens. British Journal of Dermatology, 173, 788-791.

2. Capelli G, Genchi C, Baneth G, Bourdeau P, Brianti E, Cardoso L, Danesi P, Fuehrer HP, Giannelli A, Ionică AM, Maia C, Modrý D, Montarsi F, Krücken J, Papadopoulos E, Petrić D, Pfeffer M, Savić S, Otranto D, Poppert S, Silaghi C. 2018. Recent advances on Dirofilaria repens in dogs and humans in Europe. Parasites and Vectors, 11(1), 663.

3. Chauve CM. 1997. Importance in France of the infestation by Dirofilaria (Nochtiella) repens in dogs. Parassitologia, 39(4), 393-395. 
4. Davoust B, Ducos de Lahitte J. 1986. Utilisation de l'ivermectine dans la prophylaxie de la dirofilariose canine : résultats obtenus après deux ans d'essais chez le chien militaire en zone enzootie. Bulletin de la Société Française de Parasitologie, 4(2), 235-239.

5. Davoust B, Ducos de Lahitte J. 1989. Évolution de l'enzootie de dirofilariose dans les chenils militaires du Sud-Est de la France. Revue de Médecine Vétérinaire, 140(1), 15-19.

6. Doby JM, Couatarmanach A, Aznar C. 1986. Filarioses canines par Dirofilaria immitis (Leidy, 1856) et D. repens (Railliet et Henry, 1911), dans l'ouest de la France. Bulletin de la Société Française de Parasitologie, 4(2), 229-233.

7. Doby JM, Guiguen C. 1986. Présence de Dirofilaria immitis en Bretagne. Bulletin de la Société Française de Parasitologie, 4, $51-54$.

8. Ducos de Lahitte J, Davoust B, Dorchies P. 1984. Filariose canine à Dirofilaria immitis. Enquête sur la fréquence et la répartition en zone méditerranéenne. Bulletin de la Société Française de Parasitologie, 3, 105-108.

9. Foissac M, Million M, Mary C, Dales JP, Souraud JB, Piarroux R, Parola P. 2013. Subcutaneous infection with Dirofilaria immitis nematode in human, France. Emerging Infectious Diseases, 19(1), 171-172.

10. Genchi C, Bowman D, Drake J. 2014. Canine heartworm disease (Dirofilaria immitis) in Western Europe: survey of veterinary awareness and perceptions. Parasites and Vectors, 7, 206.

11. Genchi C, Kramer L. 2017. Subcutaneous dirofilariosis (Dirofilaria repens): an infection spreading throughout the old world. Parasites and Vectors, 10(Suppl 2), 517.

12. Genchi C, Kramer LH, Rivasi F. 2011. Dirofilarial infections in Europe. Vector-Borne and Zoonotic Diseases, 11(10), 1307-1317.

13. Genchi C, Mortarino M, Rinaldi L, Cringoli G, Traldi G, Genchi M. 2011. Changing climate and changing vector-borne disease distribution: the example of Dirofilaria in Europe. Veterinary Parasitology, 176, 295-299.

14. Genchi C, Rinaldi L, Cascone C, Mortarino M, Cringoli G. 2005. Is heartworm disease really spreading in Europe? Veterinary Parasitology, 133(2-3), 137-148.

15. Giangaspero A, Marangi M, Latrofa MS, Martinelli D, Traversa D, Otranto D, Genchi C. 2013. Evidences of increasing risk of dirofilarioses in southern Italy. Parasitology Research, 112(3), 1357-1361.

16. Hall TA. 1999. BIOEDIT: a user-friendly biological sequence alignment editor and analysis program for Windows 95/98/NT. Nucleic Acids Symposium Series, 95-98.

17. Henry LG, Brunson KJ, Walden HS, Wenzlow N, Beachboard SE, L Barr K, Long MT. 2018. Comparison of six commercial antigen kits for detection of Dirofilaria immitis infections in canines with necropsy-confirmed heartworm status. Veterinary Parasitology, 254, 178-182.

18. Joyeux C, Cabassu J. 1935. Étude sur la filariose des chiens de Camargue. Bulletin de la Société de Pathologie Exotique, 28, 187-193.

19. Kartashev V, Batashova I, Kartashov S, Ermakov A, Mironova A, Kuleshova Y, Ilyasov B, Kolodiy I, Klyuchnikov A, Ryabikina E, Babicheva M, Levchenko Y, Pavlova R, Pantchev N, Morchón R, Simón F. 2011. Canine and human dirofilariosis in the Rostov Region (Southern Russia). Veterinary Medicine International, 2014, 685713.

20. Kimura M. 1981. Estimation of evolutionary distances between homologous nucleotide sequences (molecular evolution/comparison of base sequences/base substitution rate/neutral mutation-random drift hypothesis). Genetics, 78, 454-458.
21. Knott J. 1939. A method for making microfilarial surveys on day blood. Transactions of the Royal Society of Tropical Medicine and Hygiene, 33, 191-196.

22. Laidoudi Y, Davoust B, Varloud M, Niang EHA, Fenollar F, Mediannikov O. 2019. Development of a multiplexed qPCRsbased approach for the diagnosis of Dirofilaria immitis, D. repens, Acanthocheilonema reconditum and the others filariosis. bioRxiv 842575; https://doi.org/10.1101/842575.

23. Leidy J. 1856. A synopsis of entozoan and some of the other ecto-congeners observed by the author. Proceedings of Academy National of Sciences of Philadelphia, 8, 42-58.

24. Little S, Saleh M, Wohltjen M, Nagamori Y. 2018. Prime detection of Dirofilaria immitis: understanding the influence of blocked antigen on heartworm test performance. Parasites and Vectors, 11, 1-10.

25. Magnis J, Lorentz S, Guardone L, Grimm F, Magi M, Naucke TJ, Deplazes P. 2013. Morphometric analyses of canine blood microfilariae isolated by the Knott's test enables Dirofilaria immitis and D. repens species-specific and Acanthocheilonema (syn. Dipetalonema) genus-specific diagnosis. Parasites and Vectors, 6, 48.

26. Mccall JW, Genchi C, Kramer LH, Guerrero J, Venco L. 2008. Heartworm disease in animals and humans. Advances in Parasitology, 66, 193-285.

27. Ministère des Solidarités et de la Santé (France). 2019. Cartes de présence du moustique tigre (Aedes albopictus) en France métropolitaine. Web site (updated 28.05.19). https://solidaritessante.gouv.fr/sante-et-environnement/risques-microbiologiquesphysiques-et-chimiques/especes-nuisibles-et-parasites/article/cartesde-presence-du-moustique-tigre-aedes-albopictus-en-francemetropolitaine.

28. Nelson CT, McCall JW, Jones S, Moorhead A. 2018. Current canine guidelines for the prevention, diagnosis, and management of Heartworm (Dirofilaria immitis) infection in dogs. Wilmington, DE: American Heartworm Society. p. 1-35.

29. Otranto D, Dantas-Torres F, Brianti E, Traversa D, Petrić D, Genchi C, Capelli G. 2013. Vector-borne helminths of dogs and humans in Europe. Parasites and Vectors, 6, 16.

30. Panthot JB. 1679. Extrait d'une lettre écrite de Lyon à l'auteur du Journal par Monsieur Panthot D. en Méd. \& Professeur aggrégé au Collège de Lyon, contenant deux observations remarquables. Journal des Sçavans, 238.

31. Pantchev N, Schaper R, Limousin S, Norden N, Weise M, Lorentzen L. 2009. Occurrence of Dirofilaria immitis and tick-borne infections caused by Anaplasma phagocytophilum, Borrelia burgdorferi sensu lato and Ehrlichia canis in domestic dogs in France: results of a countrywide serologic survey. Parasitology Research, 105(Suppl 1), S101-S114.

32. Raccurt CP. 1999. Les dirofilarioses, des zoonoses émergentes etsous-estimées en France. Médecine Tropicale, 59(4), 389-400.

33. Railliet A, Henry A. 1911. Sur une filaire péritonéale des porcins. Bulletin de la Société de Pathologie Exotique, 4, 386-389.

34. Simón F, González-Miguel J, Diosdado A, Gómez PJ, Morchón R, Kartashev V. 2017. The complexity of zoonotic filariasis episystem and its consequences: a multidisciplinary view. BioMed Research International, 2017, 6436130.

35. Simón F, Siles-Lucas M, Morchón R, González-Miguel J, Mellado I, Carretón E, Montoya-Alonso JA. 2012. Human and animal dirofilariasis: the emergence of a zoonotic mosaic. Clinical Microbiology Reviews, 25(3), 507-544.

36. Tahir D, Bittar F, Barré-Cardi H, Sow D, Dahmani M, Mediannikov O, Raoult D, Davoust B, Parola P. 2017. Molecular survey of Dirofilaria immitis and Dirofilaria 
repens by new real-time TaqMan ${ }^{\circledR} \mathrm{PCR}$ assay in dogs and mosquitoes (Diptera: Culicidae) in Corsica (France). Veterinary Parasitology, 235, 1-7.

37. Tamura K, Stecher G, Peterson D, Filipski A, Kumar S. 2013. MEGA6: molecular evolutionary genetics analysis version 6.0. Molecular Biology and Evolution, 30(12), 2725-2729.
38. Tarello W. 2011. Clinical aspects of dermatitis associated with Dirofilaria repens in pets: a review of 100 canine and 31 feline cases (1990-2010) and a report of a new clinic case imported from Italy to Dubai. Journal of Parasitology Research, 2011, 578385.

Cite this article as: Laidoudi Y, Ringot D, Watier-Grillot S, Davoust B \& Mediannikov O. 2019. A cardiac and subcutaneous canine dirofilariosis outbreak in a kennel in central France. Parasite 26, 72.

\section{(0) PARASTE}

An international open-access, peer-reviewed, online journal publishing high quality papers on all aspects of human and animal parasitology

Reviews, articles and short notes may be submitted. Fields include, but are not limited to: general, medical and veterinary parasitology; morphology, including ultrastructure; parasite systematics, including entomology, acarology, helminthology and protistology, and molecular analyses; molecular biology and biochemistry; immunology of parasitic diseases; host-parasite relationships; ecology and life history of parasites; epidemiology; therapeutics; new diagnostic tools.

All papers in Parasite are published in English. Manuscripts should have a broad interest and must not have been published or submitted elsewhere. No limit is imposed on the length of manuscripts.

Parasite (open-access) continues Parasite (print and online editions, 1994-2012) and Annales de Parasitologie Humaine et Comparée (1923-1993) and is the official journal of the Société Française de Parasitologie. 